\title{
Types of Shelter and Covering Materials Influencing Growth, Pigment, and Nutrient Concentrations of Baby Rubber Plants (Peperomia obtusifolia)
}

Pedro García-Caparrós ${ }^{1}$, Olga González-Salmerón, Mónica Pérez-Saiz, Raquel Calatrava, and María Teresa Lao

Agronomy Department of Higher Polytechnic School and Experimental Science College, University of Almeria, Agrifood Campus of International Excellence ceiA3. Ctra. Sacramento s/n, La Cañada de San Urbano, 04120, Almería, Spain.

\section{Rosa María Chica}

Engineering Department of Higher Polytechnic School and Experimental Science College, University of Almeria, Agrifood Campus of International Excellence ceiA3. Ctra. Sacramento s/n, La Cañada de San Urbano, 04120, Almería, Spain

\section{Gumersindo De la Cruz}

Faculty of Iztacala Superior Studies, National Autonomous University of Mexico,Avenida de los Barrios Número 1, los Reyes Iztacala, Tlalnepantla 54090, Estado de México, México

Additional index words. biomass, greenhouse, nutrition, ornamental plants, net assimilation, shading

\begin{abstract}
The cultivation of ornamental plants under different types of shelter and covering materials which reduce light intensity, resulting in morphological and physiological changes, needs to be evaluated before any large-scale use of such types of shelter covers. Baby rubber plants were grown in pots filled with peat under four different shelters and covering materials as follows: MG (multitunnel greenhouse with thermo-reflective aluminised screen), BG (buried solar greenhouse with thermo-reflective aluminised screen), NH (net house covered only with antipest mesh) and NH-AS (net house with antipest mesh and thermo-reflective aluminised screen). At the end of the experiment, the growth parameters and color of leaves, as well as photosynthetic and nutritional parameters, were assessed for each treatment. Baby rubber plants grown under NH-AS showed the highest values for growth parameters. The absence of shading in a net house may result in photoinhibition, reducing the growth and increasing the values of red $(R)$ and blue $(B)$ in leaves, which may be related to the increase of anthocyanin synthesis. The low level of radiation intercepted in the multitunnel and the buried greenhouse increased chlorophyll, $N$ and $P$ leaf concentration, while for $\mathrm{K}$ concentration, there was no clear trend and $\mathrm{Na}$ and $\mathrm{Cl}$ leaf concentration were similar under the different types of shelter. We concluded that the production of baby rubber plants under net house with antipest mesh and thermo-reflective aluminised screen is the best option to maximise the market value of baby rubber plants.
\end{abstract}

Foliage plant production represents an important agricultural industry worldwide with a net wholesale value of 50 billion Euro (García-Caparrós et al., 2016; Lütken et al.,

Received for publication 20 June 2018. Accepted for publication 20 Aug. 2018.

The authors thank Timothy Flowers for his suggestions and English style corrections. The authors also thank the funding of this work by the group AGR-242 from University of Almería (Sustainability of Horticultural and Ornamental Protected Systems).

${ }^{1}$ Corresponding author. E-mail: pedrogar123@ hotmail.com.
2012). In the Mediterranean area, ornamental crops are cultivated under different types of shelter and in the open air (Pérez-Saiz et al., 2017). The greenhouse technology creates a favourable microclimate for high crop productivity and also reduces the use of fertilizers and pesticides in comparison with open field conditions (Singh et al., 2016). The main types of shelter in this area are multitunnel greenhouses covered with plastic, net houses with different covers, and the solar buried greenhouse (INSOLE) (Lao-Arenas et al., 2003). As far as the use of covering material is concerned in ornamental plant production, aluminised screen is a traditional material (Pérez-Saiz et al., 2017).

The cultivation of ornamental plants under different types of shelter and covering materials involves a reduction of the transmission of light by as much as $50 \%$, mainly due to the mechanical impedance of light by greenhouse support structures and nets (Fisher and Runkle, 2004). Plants in general have the ability to adjust to changes in environmental conditions such as low-light conditions by undergoing morphological and physiological changes (Scuderi et al., 2012). For instance, a frequent variation that results from low light availability is thinner leaves with a greater leaf area (Stanton et al., 2010) and changes in the photosynthetic response (Miralles et al., 2011). In this sense, low-light conditions may involve changes in levels of chlorophyll per chloroplast, pigments concentration and their respective ratios (Lambers et al., 1998) as occurs in Dieffenbachia maculata (Chen et al., 2005a). Changes in light conditions may also result in alteration of nutrient uptake by plants (Taiz and Zeiger, 2012).

Variegation may increase or decrease under changing light conditions and the response tends to be species specific (Vladimirova et al., 1997), but it is necessary to point out that variegated cultivars are considered less attractive when they express less foliar variegation.

We investigated the responses of Peperomia obtusifolia or "baby rubber plant" to different types of shelter and covering. Baby rubber is a popular houseplant grown all over the world belonging to the Piperaceae family. The plant is characterized by oblong, glossy green foliage and short stems (Ilyas et al., 2014). The variegated cultivar has leaves with a border of creamy white and a central zone of dark green and greyish green (Shen and Seeley, 1983). There is little information on the effects of light conditions on the growth of $P$. obtusifolia (Healy et al., 1980; Shen and Seeley, 1983). Therefore, in this trial, a pot experiment with baby rubber cv. Variegata plants was established to determine the effects of different types of shelter and covering materials on growth, photosynthetic, and nutritional parameters. Such information is essential for better understanding of the light requirements of this species and necessary for the growers of ornamental plants to optimize the production of P. obtusifolia.

\section{Material and Methods}

Types of shelter and growing conditions. The present study was carried out at the facilities of the Experimental Estate of the University of Almeria (UAL-ANECOOP) (lat. $36^{\circ} 15^{\prime} \mathrm{N}$, long. $2^{\circ} 23^{\prime} \mathrm{W}$ ). Rooted cuttings (plants) of baby rubber cv. Variegata were obtained from a local nursery and transplanted into $2 \mathrm{~L}$ polyethylene pots containers (one plant per container) containing peat-moss (Kekkilä Finnpeat; Projar, Valencia, Spain) with the following characteristics 
in the saturated extract [pH: 5.5, electrical conductivity (EC): $\left.2 \mathrm{dS} \cdot \mathrm{m}^{-1}\right]$ and nutrients concentration expressed in $\mathrm{mg} \cdot \mathrm{L}^{-1}[120(\mathrm{~N})$, $90(\mathrm{~K}), 150(\mathrm{~K}), 100(\mathrm{Ca})$, and $30(\mathrm{Mg})]$. During the trial (from June 2015 to July 2016), the pots were placed in four different types of shelter or treatments. The first shelter was a multitunnel greenhouse (MG) of $540 \mathrm{~m}^{2}$ composed of three tunnels with the following dimensions: height $4.5 \mathrm{~m}$, width $8 \mathrm{~m}$, and length $22.5 \mathrm{~m}$. The covering material was a thermal plastic polyethylene of 800 gauge $(0.25 \mathrm{~mm})$ and a thermoreflective aluminised screen under the polyethylene cover. The second type of shelter was a buried solar greenhouse (BG) designed following the guidelines established by Jimenez (1986) and Lao-Arenas et al., (2003). This type of installation is designed for the production of ornamental plants with high thermal requirements and a low point of saturation light. The buried solar greenhouse had an area of $480 \mathrm{~m}^{2}$ composed of three tunnels with the following dimensions: height $4.5 \mathrm{~m}$, width $8 \mathrm{~m}$, and length $20 \mathrm{~m}$. The covering material was a thermal plastic polyethylene of 800 gauge $(0.25 \mathrm{~mm})$ and a thermo-reflective aluminised screen under the polyethylene cover. The third type of shelter was a net house $(\mathrm{NH})$ covered by antipest mesh of $20 \times 10$ threads. The net house was $540 \mathrm{~m}^{2}$ in area, composed of three tunnels with the following dimensions: height $4.5 \mathrm{~m}$, width $8 \mathrm{~m}$, and length $22.5 \mathrm{~m}$. The fourth shelter was also a net house covered with antipest mesh of $20 \times 10$ threads and a thermo-reflective aluminised screen under the antipest mesh cover (NH-AS). The area of the net house was $540 \mathrm{~m}^{2}$, and it was composed of three tunnels with the following dimensions: height $4.5 \mathrm{~m}$, width $8 \mathrm{~m}$, and length $22.5 \mathrm{~m}$.

Temperature and relative humidity inside each type of shelter were monitored continuously with four data loggers (HOBO SHUTTLE model U12-012; Onset Computer Corp., Bourne, MA). Spectral radiation from 300 to $1100 \mathrm{~nm}$, at $5 \mathrm{~nm}$ intervals, was measured with a portable spectroradiometer (LI-1800; LI-COR Biosciences, Lincoln, NE) located at $1.5 \mathrm{~m}$ above the ground in the middle of each installation. Measurements from outside the installations were collected from a weather station located at UAL-ANECOOP.

The nutrient solution supplied during the experiment in all treatments had the following composition (in mmol. $\mathrm{L}^{-1}$ ): 2.7 nitrogen $(\mathrm{N}), 0.7$ phosphorus $(\mathrm{P}), 1.3$ sulfur $(\mathrm{S}), 8$ chloride $\left(\mathrm{Cl}^{-}\right), 5$ potassium $\left(\mathrm{K}^{+}\right), 5$ calcium $\left(\mathrm{Ca}^{2+}\right), 4$ magnesium $\left(\mathrm{Mg}^{2+}\right)$, and 9 sodium $\left(\mathrm{Na}^{+}\right)$, an EC of $2.50 \mathrm{dS} \cdot \mathrm{m}^{-1}$ and $\mathrm{pH}$ of 5.8 . Plants were monitored weekly and watered daily with $50 \mathrm{~mL}$ per plant in each treatment. The experimental design was a randomized block design consisting of four different types of shelter/covering materials, four replicates and six plants (one plant per pot) per replicate giving a total of 24 plants per treatment plus border plants.

Color parameters and photosynthetic pigments concentration. At the end of the experiment, six plants per treatment were randomly selected to determine color parameters and concentration of photosynthetic pigments. The color index in the leaf green area for red $(\mathrm{R})$, green $(\mathrm{G})$, and blue $(\mathrm{B})$ values was assessed following the methodology established by Kim et al. (2012). Briefly, the RGB values were determined using an optical scanner (ES-2000; Seiko Epson Corp., Suwa, Japan) and the images were processed with Adobe Photoshop CS6 (Adobe System Software, Dublin, Ireland) by averaging the $\mathrm{R}, \mathrm{G}$, and $\mathrm{B}$ values of all the leaf pixels. The same plants designated for the determination of leaf color index were also used to determine the concentrations of photosynthetic pigments. Extraction of chlorophyll $a$ and $b$ (Chl $a$ and $\mathrm{Chl} b$ ) and carotenoids were performed by submerging $0.2 \mathrm{~g}$ of fresh mature leaves (green area) in methanol in the dark at room temperature $\left(15^{\circ} \mathrm{C}\right)$ for $24 \mathrm{~h}$. The supernatant was removed, and the photosynthetic pigment concentrations were determined colorimetrically at their respective wavelengths in a Shimadzu ultraviolet-1201 spectrophotometer (Shimadzu Scientific Instruments, Columbia, MD): Chl $a(\lambda=666 \mathrm{~nm})$, Chl $b(\lambda=653$ $\mathrm{nm})$, and carotenoids $(\lambda=470 \mathrm{~nm})$ following the methodology of Wellburn (1994).

Growth parameters. At the end of the experiment, the same plants used to determine color parameters and photosynthetic pigments were used for measurements of growth parameters. Plant height from the top edge of the container to the last open leaf of the plant crown was measured. Maximum plant diameter was determined across the top of the plant and the number of leaves of each plant counted. Leaf area was determined before photosynthetic determinations from digitalized images of each plant using the Idrisi Selva computer program (Clark Laboratories, Worcester, MA) as reported by García-Caparrós et al. (2017). Specific leaf area was calculated by dividing leaf area by plant dry weight. Due to the semispherical shape of this species, plant volume was calculated from the semispheroid volume (Fig. 1). Variegation index was calculated as (whole leaf area - green area)/(whole leaf area) following the methodology established by $\mathrm{Li}$ et al. (2007). The aerial part was divided into stems (S), mature leaves (ML), young leaves (YL), buds (B), and petioles (P) and the respective fresh weights $(\mathrm{FW})$ were measured, then oven-dried at $60^{\circ} \mathrm{C}$ until they reached a constant dry weight (DW). Aerial part dry weight (ADW) was calculated as the sum of stems, mature leaves, young leaves, buds, and petioles. The fresh and dry weight of the aerial part were used to calculate the water content (WC) as:

$$
\mathrm{WC}=(\mathrm{FW}-\mathrm{DW}) / \mathrm{DW}
$$

Ion concentrations in leaves. The ovendried samples of mature leaves were milled (Grindomix GM 200; Retsch Gmbh, Haan, Germany), cleaning the mill between samples. Each sample was divided in two subsamples.

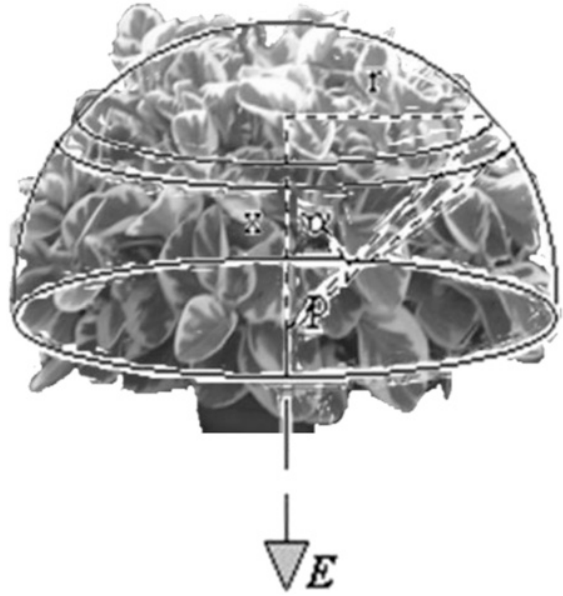

Fig. 1. Semispheroidal shape of Peperomia obtusifolia plants $\left[\mathrm{V}\right.$ (volume) $=3 / 4 \cdot \amalg \cdot \mathrm{r}^{2} \cdot \mathrm{h}(\mathrm{r}=$ radium of the plant, $\mathrm{h}=$ height of the plant).

One subsample was used to analyze chloride and nitrate $\left(\mathrm{NO}_{3}\right)$ concentration using water extraction and HPLC as described by Csáky and Martínez-Grau (1998). The other subsamples were mineralized with $96 \%$ sulphuric acid $\left(\mathrm{H}_{2} \mathrm{SO}_{4}\right)$ in the presence of P-free hydrogen peroxide $\left[\mathrm{H}_{2} \mathrm{O}_{2}, 30 \%(\mathrm{w} / \mathrm{v})\right]$ at $300^{\circ} \mathrm{C}$ and used for the determination of organic $\mathrm{N}$ (Krom, 1980), total P (Hogue et al., 1970), and $\mathrm{K}^{+}$and $\mathrm{Na}^{+}$(Lachica et al., 1973) concentrations. Total $\mathrm{N}$ concentration was calculated as the sum of the organic $\mathrm{N}$ and $\mathrm{NO}_{3}{ }^{-}$ concentration.

Statistical analysis. The values obtained for each plant and each variable were considered as independent replicates. The data were analyzed through one-way analysis of variance and Fisher's least significant difference test was performed using Statgraphics Centurion XVI.II (Statpoint Technologies, Inc. Warrenton, VA) to assess the differences between treatments.

\section{Results}

Climatic conditions inside the types of shelter. Daily global radiation $(G R)$, photosynthetically active radiation $(P A R)$, minimum temperature $\left(\mathrm{T}_{\min }\right)$, mean temperature $\left(\mathrm{T}_{\text {mean }}\right)$, maximum temperature $\left(\mathrm{T}_{\max }\right)$, and relative humidity $(\mathrm{RH})$ inside each type of shelter during the crop cycle are presented in Table 1. The values of temperature inside of all types of shelter were higher compared with the outside conditions, with the buried greenhouse having the highest value of all treatments. Net houses were cooler than the other structures and warmer than the outside conditions. Moreover, the addition of the thermo-reflective aluminised screen in the net house resulted in an increase of temperature of $\approx 0.5{ }^{\circ} \mathrm{C}$. The values of relative humidity inside of all types of shelter were lower compared with the outside conditions, again with the buried greenhouse having the highest value of all treatments. The values of $G R$ and $P A R$ were lower than outside; the net house with antipest mesh had the highest values of all the treatments. The daily 
Table 1. Averages of maximum, mean, and minimum temperatures (in ${ }^{\circ} \mathrm{C}$ ), relative humidity $(\mathrm{RH}$ in $\%$ ), global radiation $\left(G R\right.$ in $\left.\mathrm{MJ} \cdot \mathrm{m}^{-2} \cdot \mathrm{d}^{-1}\right)$ and photosynthetically active radiation $\left(P A R\right.$ in $\mathrm{MJ} \cdot \mathrm{m}^{-2} \cdot \mathrm{d}^{-1}$ and $\left.\mu \mathrm{mol} \cdot \mathrm{m}^{-2} \cdot \mathrm{s}^{-1}\right)$ in each shelter typology.

\begin{tabular}{|c|c|c|c|c|c|}
\hline \multirow[b]{2}{*}{ Parameters } & \multirow[b]{2}{*}{ Outdoor } & \multicolumn{4}{|c|}{ Shelter typologies } \\
\hline & & $\mathrm{MG}$ & $\mathrm{BG}$ & $\mathrm{NH}$ & NH-AS \\
\hline$\overline{\mathrm{T}_{\min }\left({ }^{\circ} \mathrm{C}\right)}$ & 13.9 & 15.8 & 18.9 & 14.7 & 15.2 \\
\hline $\mathrm{T}_{\text {mean }}\left({ }^{\circ} \mathrm{C}\right)$ & 18.5 & 21.5 & 22.6 & 20.2 & 20.6 \\
\hline $\mathrm{T}_{\max }\left({ }^{\circ} \mathrm{C}\right)$ & 23.3 & 27.5 & 28.6 & 26.0 & 26.5 \\
\hline RH (\%) & 78.2 & 64.5 & 71.7 & 64.4 & 64.7 \\
\hline$G R\left(\mathrm{MJ} \cdot \mathrm{m}^{-2} \cdot \mathrm{d}^{-1}\right)$ & 19.3 & 3.8 & 3.4 & 11.5 & 6.7 \\
\hline$P A R\left(\mathrm{MJ} \cdot \mathrm{m}^{-2} \cdot \mathrm{d}^{-1}\right)$ & 10.6 & 2.0 & 1.9 & 6.2 & 3.6 \\
\hline PAR $\left(\mu \mathrm{mol} \cdot \mathrm{m}^{-2} \cdot \mathrm{s}^{-1}\right)$ & 520.5 & 98.2 & 93.3 & 304.4 & 176.8 \\
\hline
\end{tabular}

$\mathrm{MG}=$ multitunnel greenhouse, $\mathrm{BG}=$ buried solar greenhouse, $\mathrm{NH}=$ net house with antipest mesh, and $\mathrm{NH}-$ $\mathrm{AS}=$ net house with antipest mesh and aluminised screen.

fluctuations of climatic measurements throughout the experiment in each shelter typology are presented in Fig. 2. The buried greenhouse showed the least climatic fluctuation between all types of shelter over the experiment.

Color parameters and photosynthetic pigments concentration. Baby rubber plants grown in the net house with only antipest mesh had the highest values of $\mathrm{R}$ and $\mathrm{B}$ at the end of the experiment. No differences in $G$ values were found in plants grown under different types of shelter (Table 2).

Plants grown in multitunnel and buried greenhouses had significantly higher values for chlorophyll concentrations ( $a, b$, and $a+b$ ) in leaves. Carotenoids concentration and ratio Chl $a / b$ in leaves did not show significant differences between treatments (Table 2).

Growth parameters. Throughout the experiment, there were no mortalities or any visual damage evident on the plants in response to the growth under different types of shelter. There were no differences in plant height and water content between all treatments at the end of the experiment. Baby rubber plants grown in net houses with antipest mesh and thermo-reflective aluminised screens showed the highest values of diameter, number of leaves, leaf area, specific leaf area, volume, and total aerial dry weight. At the end of the experiment, variegation index had the highest value in plants grown in the buried greenhouse (Table 3 ).

In the aerial part, dry weight partitioning of plants grown in net houses with antipest mesh and thermo-reflective aluminised screen had the highest values for dry weight of stem, leaves, young leaves, buds, and petioles. Baby rubber plants only developed young leaves when grown in net houses (Fig. 3).

Ion concentrations in leaves. In baby rubber plants, leaf $\mathrm{N}$ and $\mathrm{P}$ showed the highest concentrations in multitunnel and buried greenhouses with low-light conditions. The leaf $\mathrm{K}$ did not show a clear trend under different treatments but the lowest values were recorded from net houses. The leaf $\mathrm{Na}$ and $\mathrm{Cl}$ level was unaffected by level of irradiance intercepted in each type of shelter (Table 4).

\section{Discussion}

The use of different types of shelter resulted in an increase of temperature inside compared with outside conditions, which is positive for the growth of ornamental plants. This phenomenon has also been reported by Kittas et al. (2003) and Callejón-Ferre et al. (2009) in a greenhouse shaded with aluminised screens. Lower temperatures in net houses compared with the other types of shelter can be due to the higher air exchange rate as reported by Stamps (2009). With respect to the outside conditions, an increase of temperatures in net houses has also been reported by Villegas et al. (2006) in an experiment with different degrees of shading on the growth of Cyclamen persicum. The highest temperatures and relative humidity occurred in the buried greenhouse and are related to the design of this type of shelter. During the night, heat stored in floors and walls is transferred to the greenhouse atmosphere, while the presence of micro sprinklers established in the design of this shelter generates an increase of the relative humidity to simulate tropical conditions (Lao-Arenas et al., 2003). In our experiment, the addition of a thermo-reflective aluminised screen in the net house resulted in a slight increase of thermal property of the shade covering. Similar results were reported by FernandezRodriguez et al. (2002) in two commercial greenhouses covered with polyethylene and aluminised thermo-reflective shading screens with two levels of shading (40\% and 50\%). The lower values of RH inside of all types of shelter compared with the outside conditions follows from the increase of temperature found in all treatments as reported Kittas et al. (2003). The use of different covering materials reduced the radiation intercepted by the canopy, agreeing with the results reported by Stamps (2009); the highest value of radiation was found in the net house with only antipest mesh and may be ascribed to the absence of a shade covering.

Color is used as an important parameter for measuring plant health and quality in ornamental plants (Dominguez et al., 2017). The highest value of $\mathrm{R}$ and $\mathrm{B}$ found in our experiment with baby rubber was in plants grown under the net house with only antipestmesh and may follow from the synthesis of anthocyanins to counteract the effects of photoinhibition. Anthocyanins are plant pigments produced by the flavonoid biosynthetic temperature which was likely due to the pathway and comprise the red and blue pigmentation of many plants (Islam et al., 2005). There is evidence that anthocyanins can protect photosynthetic tissues from photoinhibition by absorbing blue-green light and thereby reducing the amount of light reaching the chloroplasts (Hughes et al., 2005; Merzlyak et al., 2008).

Previous studies have shown that low levels of light could alter the contents of photosynthetic pigments, of which chlorophyll $a$ and $b$ and $a / b$ were important indicators for assessing the optimal light intensity for a species (Zhang et al., 2009). In our experiment, leaf chlorophyll concentration [Chl $a$, Chl $b$, and total chlorophyll $(a+b)]$ significantly increased as the light flux density decreased. Similar results were obtained by Jeong and Pasian (2007) for six Begonia sp. grown under low irradiance and by Hatamian and Salehi (2017) in rose plants grown under increasing shading levels (1200 to $\left.240 \mu \mathrm{mol} \cdot \mathrm{m}^{-2} \cdot \mathrm{s}^{-1}\right)$. The results obtained in our experiment agree with previous literature where plants grown under low levels of light irradiance showed higher levels of chlorophyll concentration; this increase helps a plant to maximize light interception in low light environments (Close et al., 2001). The lowest values of chlorophyll concentration in baby rubber plants were in plants grown in the net house with only antipest mesh; this could be related to photoinhibition that damaged the photosynthetic reaction centers under high light levels of irradiance. This process of photoinbition was also reported by Andersen et al. (1991) in plants of Aucuba japonica grown under conditions of full sun and under shadecloth (light transmittance of $69 \%, 47 \%$, and $29 \%$ full sun) over 2 years. In our experiment, $\mathrm{Chl} a / b$ ratio was unaffected by the level of irradiance intercepted by the canopy in each type of shelter. Similarly, Sarracino et al. (1992) reported that $\mathrm{Chl} a / b$ ratio remained unchanged in Leea coccinia plants grown in response to different light flux densities, and Meng et al. (2008) showed no consistent patterns of Chl $a / b$ ratio in three Lycoris sp. grown under three levels of irradiance $(100 \%, 70 \%$, and $30 \%$ full sunlight). Therefore, in our experiment, the chlorophyll $a / b$ ratio appears to be a poor indicator of the response of baby rubber plants to different light conditions. The absence of variation in carotenoid concentrations in our experiment was in line with the findings reported by Zhang et al. (2016) for two Physocarpus sp. under different light regimes.

The use of different types of shelter and covering material had different effects on growth parameters in baby rubber plants. At the end of the experiment, the absence of effects on plant height could be due to the semispherical habit of this species, which did not change in height. No differences in plant height were also observed in Verbena hybrida plants grown under three different fixedwoven shade cloths providing $38 \%, 61 \%$, or $86 \%$ shade or no shade (Hutchinson et al., 2012), while plant height increased in other 
$\mathrm{NH}$

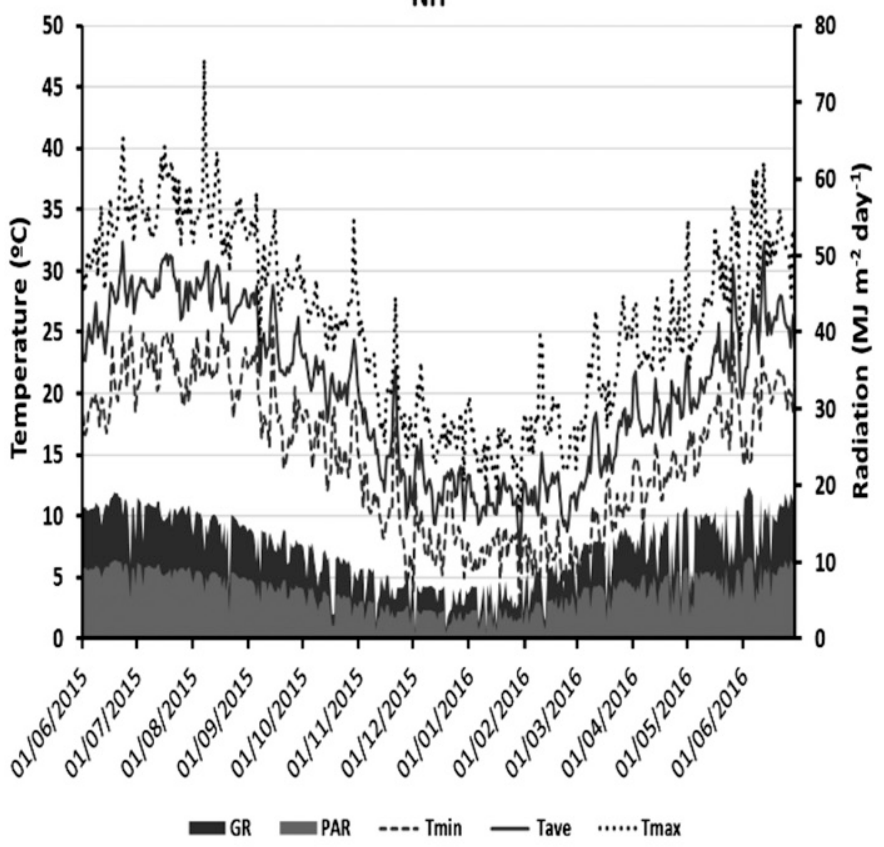

MG

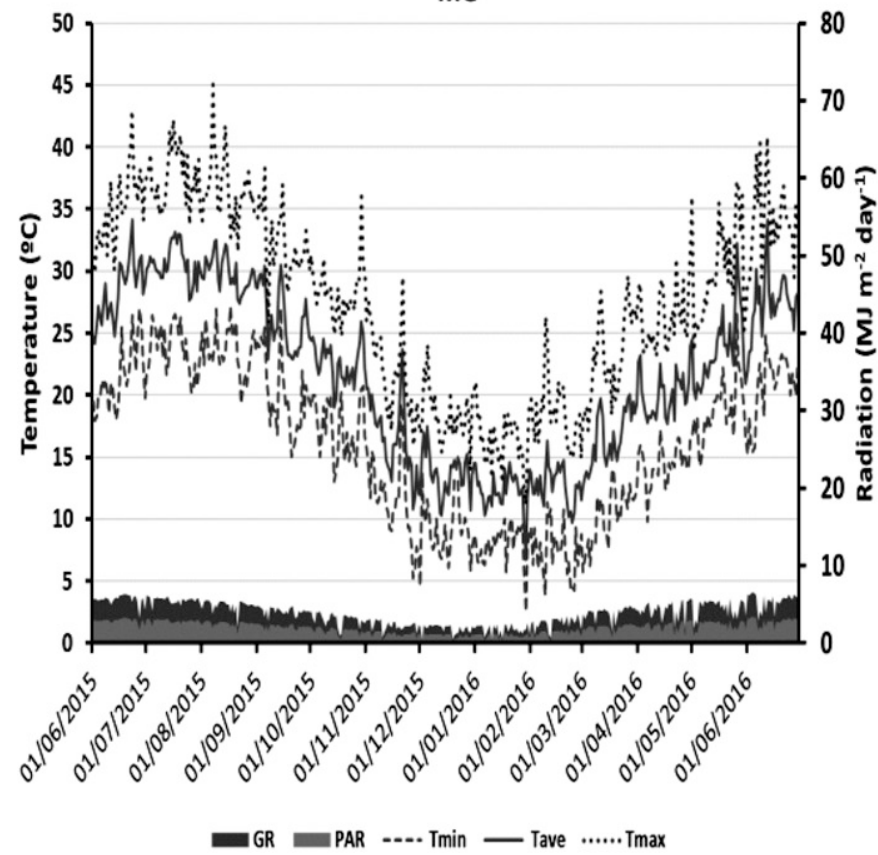

NH-AS

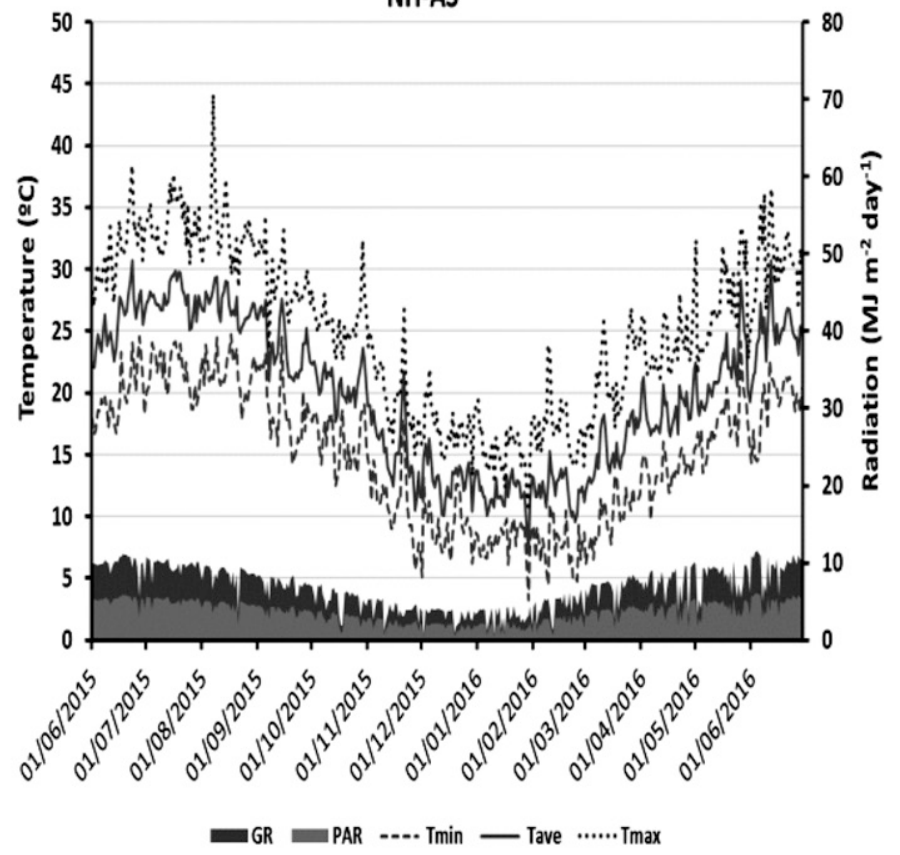

BG

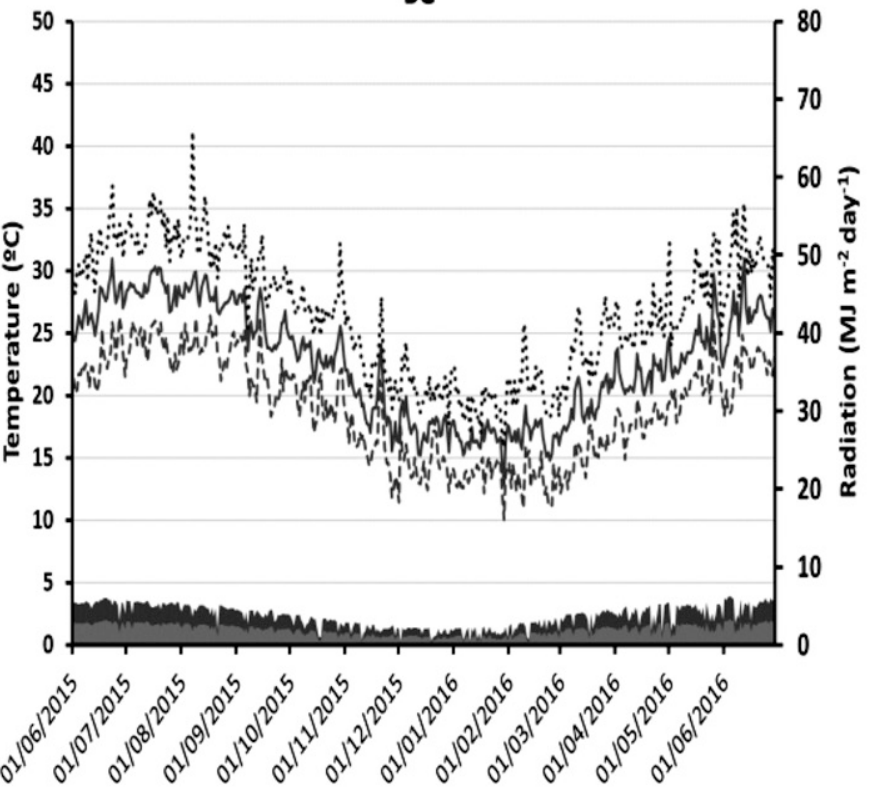

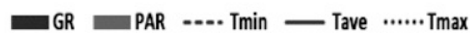

Fig. 2. Time course of climatic parameters in each shelter typology throughout the experiment. $G R=$ global radiation $\left(\mathrm{MJ} \cdot \mathrm{m}^{-2} \cdot \mathrm{d}^{-1}\right), P A R=$ photosynthetically active radiation $\left(\mathrm{MJ} \cdot \mathrm{m}^{-2} \cdot \mathrm{d}^{-1}\right)$, Tmin $=$ minimum temperature, Tave $=$ average temperature, and Tmax $=$ maximum temperature (temperature are expressed in $\left.{ }^{\circ} \mathrm{C}\right) . \mathrm{MG}=$ multitunnel greenhouse, $\mathrm{BG}=$ buried solar greenhouse, $\mathrm{NH}=$ net house with antipest mesh and $\mathrm{NH}-\mathrm{AS}=$ net house with antipest mesh and aluminised screen.

ornamental plants as Paeonia lactiflora (Zhao et al., 2012) and Tecoma stans (Torres and Lopez, 2011) under high levels of irradiance. At the end of the experiment, plant diameter, number of leaves, leaf area, specific leaf area, plant volume, and aerial dry weight had the highest value in baby rubber plants grown in net houses with antipest mesh and thermoreflective aluminised screen. The high growth of this species under this shelter can be explained in the following way: The values of PAR (around $2 \mathrm{MJ} \cdot \mathrm{m}^{-2} \cdot \mathrm{d}^{-1}$ ) received by plants in the multitunnel greenhouse and buried greenhouse compared with other shelters were lower than the values reported by $\mathrm{Di}$ Benedetto (2004) as optimal light intensity for growth in shade ornamental plants (172 $\mu \mathrm{mol} \cdot \mathrm{m}^{-2} \cdot \mathrm{s}^{-1}$ and $\approx 3.5 \mathrm{MJ} \cdot \mathrm{m}^{-2} \cdot \mathrm{d}^{-1}$ ) and was only achieved in the net house with antipest mesh and thermo-reflective aluminised screen. The increase of minimum temperature, especially during the night, and relative humidity in the buried greenhouse did not result in a higher plant growth compared with baby rubber plants grown in the multitunnel greenhouse. This result contrasts with other research in which there was a positive effect with an increase in temperature under different light conditions on the growth of several ornamental plant species, such as Celosia argentea and Impatiens walleriana (Pramuk and Runkle, 2005) and Cyclamen persicum (Cheon et al., 2006). In the case of baby rubber plants grown in the net house with only antipest mesh, photoinhibition may have resulted from the high values of radiation 
Table 2. Mean color index in leaves [(red (R), green (G), blue (B) values)] and photosynthetic pigment [chlorophyll (Chl) and carotenoids] concentrations of baby rubber grown in $2 \mathrm{~L}$ (0.53 gal) pots containing peatmoss. Treatments consisted of a multitunnel greenhouse (MG), buried solar greenhouse (BG), net house with antipest mesh $(\mathrm{NH})$, and net house with antipest mesh and aluminised screen (NH-AS).

\begin{tabular}{|c|c|c|c|c|c|c|c|c|}
\hline \multirow[b]{3}{*}{ Shelter typologies } & \multicolumn{6}{|c|}{ Parameters } & \multirow[b]{3}{*}{ Chl $a / b$ ratio } & \multirow{3}{*}{$\begin{array}{c}\text { Chl } a+b \\
\left(\mathrm{mg} \cdot \mathrm{g}^{-1} \mathrm{FW}\right)\end{array}$} \\
\hline & \multicolumn{3}{|c|}{ Color } & \multirow{2}{*}{$\begin{array}{c}\text { Chl } a \\
\left(\mathrm{mg} \cdot \mathrm{g}^{-1} \mathrm{FW}\right)^{\mathrm{z}}\end{array}$} & \multirow{2}{*}{$\begin{array}{c}\mathrm{Chl} b \\
\left(\mathrm{mg} \cdot \mathrm{g}^{-1} \mathrm{FW}\right)\end{array}$} & \multirow{2}{*}{$\begin{array}{l}\text { Carotenoids } \\
\left(\mathrm{mg} \cdot \mathrm{g}^{-1} \mathrm{FW}\right)\end{array}$} & & \\
\hline & $\mathrm{R}$ & $\mathrm{G}$ & B & & & & & \\
\hline$\overline{\mathrm{MG}}$ & $88.4 b^{y}$ & $119.5 \mathrm{a}$ & $65.8 \mathrm{~b}$ & $2.7 \mathrm{a}$ & $1.5 \mathrm{a}$ & $0.3 \mathrm{a}$ & $1.8 \mathrm{a}$ & $4.2 \mathrm{a}$ \\
\hline $\mathrm{BG}$ & $89.1 \mathrm{~b}$ & $120.5 \mathrm{a}$ & $66.2 \mathrm{~b}$ & $2.6 \mathrm{a}$ & $1.4 \mathrm{a}$ & $0.3 \mathrm{a}$ & $1.8 \mathrm{a}$ & $4.1 \mathrm{a}$ \\
\hline $\mathrm{NH}$ & $94.0 \mathrm{a}$ & $122.4 \mathrm{a}$ & $71.1 \mathrm{a}$ & $1.5 \mathrm{c}$ & $0.8 \mathrm{c}$ & $0.3 \mathrm{a}$ & $1.8 \mathrm{a}$ & $2.3 \mathrm{c}$ \\
\hline NH-AS & $89.2 \mathrm{~b}$ & $120.3 \mathrm{a}$ & $65.5 \mathrm{~b}$ & $2.2 \mathrm{~b}$ & $1.2 \mathrm{~b}$ & $0.4 \mathrm{a}$ & $1.8 \mathrm{a}$ & $3.4 \mathrm{~b}$ \\
\hline
\end{tabular}

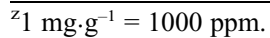

${ }^{\mathrm{y}}$ Means within a column with the same letter are not significantly different at $P<0.05$ (analysis of variance and least significant difference test). $\mathrm{n}=6$.

Table 3. Mean plant height, plant diameter, leaf number, leaf area, specific leaf area, plant volume, variegation index (VI), leaf water content, and aerial part dry weight of baby rubber grown in $2 \mathrm{~L}(0.53 \mathrm{gal})$ pots containing peatmoss. Treatments consisted of a multitunnel greenhouse (MG), buried solar greenhouse (BG), net house with antipest mesh (NH), and net house with antipest mesh and aluminised screen (NH-AS).

\begin{tabular}{|c|c|c|c|c|c|c|c|c|c|}
\hline \multirow[b]{2}{*}{$\begin{array}{l}\text { Shelter } \\
\text { typologies }\end{array}$} & \multicolumn{9}{|c|}{ Growth parameters } \\
\hline & Plant ht $(\mathrm{cm})^{\mathrm{z}}$ & Diam $(\mathrm{cm})$ & $\begin{array}{c}\text { Leaves } \\
\text { (no.) }\end{array}$ & $\begin{array}{c}\text { Leaf } \\
\text { area }\left(\mathrm{m}^{2}\right)\end{array}$ & $\begin{array}{c}\text { Specific leaf } \\
\text { area }\left(\mathrm{cm}^{2} \cdot \mathrm{g}^{-1}\right)\end{array}$ & $\begin{array}{c}\text { Plant } \\
\text { volume }\left(\mathrm{m}^{3}\right)\end{array}$ & $\begin{array}{c}\text { Variegation } \\
\text { index (-) }\end{array}$ & $\begin{array}{l}\text { Leaf water } \\
\text { content (-) }\end{array}$ & $\begin{array}{l}\text { Aerial dry wt } \\
\text { per plant }(\mathrm{g})\end{array}$ \\
\hline MG & $34.5 \mathrm{a}^{\mathrm{y}}$ & $138.7 \mathrm{c}$ & $203.7 \mathrm{c}$ & $0.7 \mathrm{c}$ & $91.5 \mathrm{c}$ & $0.1 \mathrm{c}$ & $0.3 \mathrm{~b}$ & $12.1 \mathrm{a}$ & $73.5 \mathrm{c}$ \\
\hline $\mathrm{BG}$ & $34.7 \mathrm{a}$ & $190.5 \mathrm{~b}$ & $295.7 \mathrm{~b}$ & $1.0 \mathrm{~b}$ & $112.4 \mathrm{~b}$ & $0.2 \mathrm{~b}$ & $0.4 \mathrm{a}$ & $12.4 \mathrm{a}$ & $127.5 \mathrm{~b}$ \\
\hline $\mathrm{NH}$ & $35.8 \mathrm{a}$ & $189.0 \mathrm{~b}$ & $333.0 \mathrm{~b}$ & $1.0 \mathrm{~b}$ & $115.0 \mathrm{~b}$ & $0.2 \mathrm{~b}$ & $0.2 \mathrm{c}$ & $13.2 \mathrm{a}$ & $133.4 \mathrm{~b}$ \\
\hline NH-AS & $34.2 \mathrm{a}$ & $233.2 \mathrm{a}$ & $452.5 \mathrm{a}$ & $1.5 \mathrm{a}$ & $141.4 \mathrm{a}$ & $0.3 \mathrm{a}$ & $0.3 \mathrm{~b}$ & $12.6 \mathrm{a}$ & $212.6 \mathrm{a}$ \\
\hline
\end{tabular}

${ }^{\mathrm{z}} 1 \mathrm{~cm}=0.3937$ inch, $1 \mathrm{~m}^{2}=10.7639 \mathrm{ft}^{2}, 1 \mathrm{~g}=0.0353 \mathrm{oz}, 1 \mathrm{~mL}=0.0338 \mathrm{fl} \mathrm{oz}$.

${ }^{\mathrm{y}}$ Means within a column with the same letter are not significantly different at $P<0.05$ (analysis of variance and least significant difference test).

inside $\left(6.2 \mathrm{MJ} \cdot \mathrm{m}^{-2} \cdot \mathrm{d}^{-1}\right)$, which are higher than the levels of radiation reported by $\mathrm{Di}$ Benedetto (2004) $\left(250 \mu \mathrm{mol} \cdot \mathrm{m}^{-2} \cdot \mathrm{s}^{-1}\right.$ and $\approx 5.1$ $\left.\mathrm{MJ} \cdot \mathrm{m}^{-2} \cdot \mathrm{d}^{-1}\right)$, from which plants suffered a growth reduction. Concerning the number of leaves, several studies reported an increase in leaf number with increasing levels of irradiance in different ornamental species such as Begonia $\times$ semperflorens-cultorum Hort. (Nemali and van Iersel, 2004) and Cyclamen persicum (Oh et al., 2009), whereas others reported a decrease of the number of leaves - e.g., in Cordyline terminalis under high-light conditions (Gaurav et al., 2015). On the other hand, the highest rate of growth of baby rubber plants, which occurred under net house with antipest mesh and thermoreflective aluminised screen, also resulted in the highest value of diameter and volume. These results agree with those of Evans and Poorter (2001) who reported an increase in growth in different species under optimal light intensities as occurred in our experiment.

High levels of irradiance can result in a decrease or in an increase in leaf area, depending on the species studied. For instance, Kubatsch et al. (2007) and Garland et al. (2010) reported an increase of leaf area under high levels of irradiance in Schefflera arboricola and Solenostemon scutellarioides, whereas other studies reported a decrease in leaf area in ornamental species such as Spiraea tomentosa (Stanton et al., 2010). The specific leaf area can also show different trends under high levels of radiation intercepted by the canopy. Some researchers have reported that plants grown under low light intensity generally have thin leaves resulting in a high specific leaf area as happened in Dracaena sanderiana (Vladimirova et al., 1997) and Ficus benjamina (Scuderi et al., 2012), while others reported a decrease and consequently the formation of thick leaves in ornamental species such as Petunia hybrida,
Pelargonium hortorum, and Impatiens hawkeri (Currey and Lopez, 2015).

As far as the partitioning of the aerial parts was concerned, it is necessary to point out that only in baby rubber plants grown under net house conditions were young leaves present, a consequence of a greater photosynthetic capacity and a higher plant dry weight. These results were in line with a research conducted by Sipes and Ting (1985) in which the presence of young leaves in Peperomia camptotricha resulted in a higher rate of photosynthesis compared with older leaves and consequently in a higher rate of growth.

Worth noting is the variegation index, since undesired changes in foliar variegation often result in significant loss of market value (Henny and Chen, 2003). In our experiment, baby rubber plants grown in the buried greenhouse showed the highest variegation index at the end of the experiment. Variegation may increase or decrease under high light conditions and the response tends to be species specific (Vladimirova et al., 1997). Foliage crops including Aspidistra elatior (Stamps, 1995), Codiaeum variegatum (Hong et al., 1994), Epipremnum aureum (Nam et al., 1997), and Hedera helix (Pennisi et al., 2005) were more variegated under high light intensity whereas Dracaena sanderiana and Peperomia obtusifolia, both shade obligate species, were more variegated when grown under low light (Shen and Seeley, 1983; Vladimirova et al., 1997). Selection of an appropriate light levels in greenhouses is essential to producing and maintaining variegated foliage plants with the greatest aesthetic appeal as reported by Chen et al. (2005b).

The use of different types of shelter and covering material did not affect the leaf water content in baby rubber plants. These results are consistent with Hatamian and Salehi (2017) who reported no changes in leaf water content in rose plants grown under different shading treatments. The absence of variation in leaf water content in baby rubber plants can be related to the high degree of succulence as reported by Kaul (1977), which can remain unchanged under different light conditions.

There are a limited number of studies on mineral nutrient uptake by ornamental crops as affected by light conditions. The increased foliar $\mathrm{N}$ and $\mathrm{P}$ concentrations observed in our study in response to low light conditions (mutitunnel and buried greenhouses) are consistent with reports on other ornamental plants grown under low levels of irradiance. For instance, Frantz and Ling (2011) reported an increase of $\mathrm{N}$ and $\mathrm{P}$ concentration in Petunia hybrida grown under low light conditions. Rouphael et al. (2008) also reported that $\mathrm{N}$ and $\mathrm{P}$ uptake in Pelargonium hortorum was significantly greater in winter than in spring. Increased foliar $\mathrm{N}$ concentration in shaded plants has been associated with increased leaf chlorophyll concentration, a plant response intended to increase light capture under shaded conditions (de Groot et al., 2002). On the other hand, Bres and Jerzy (2008) noted a decrease of $\mathrm{N}$ and $\mathrm{P}$ concentration in chrysanthemum leaves under high levels of irradiance. With respect to $\mathrm{K}$ concentration in leaves, our results no showed relationship with level of irradiance intercepted by the canopy in any of the shelter treatments, as reported by Mengel and Kirkby (2001). The low values of K concentration in plants grown in the net houses may be ascribed to a dilution effect mainly due to the biomass increase as reported by Marschner (1995). The $\mathrm{Na}$ and $\mathrm{Cl}$ concentrations were unchanged under different types of shelter, suggesting that $\mathrm{Cl}$ and $\mathrm{Na}$ uptake were not controlled by the light intensity (Maathuis, 2013; White and Broadley, 2001).

Our results showed that different types of shelter and covering material triggered 


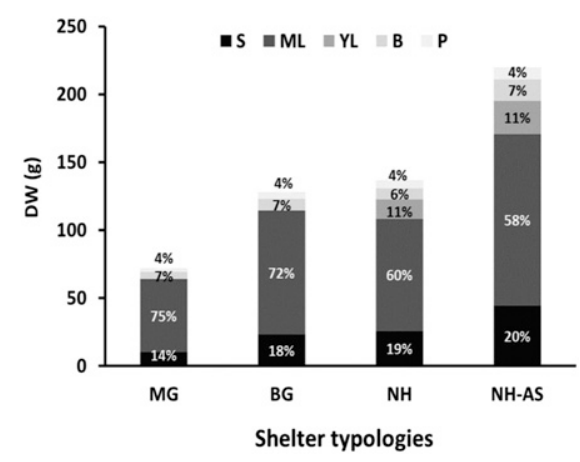

Fig. 3. Total aerial part dry weight and partitioning in stems (S), mature leaves (ML), young leaves $(\mathrm{YL})$, buds $(\mathrm{B})$, and petioles $(\mathrm{P})$ in each shelter typology.

Table 4. Mean leaf nutrient concentration of baby rubber grown in $2 \mathrm{~L}(0.53 \mathrm{gal})$ pots containing peatmoss. Treatments consisted of a multitunnel greenhouse (MG), buried solar greenhouse (BG), net house with antipest mesh (NH) and net house with antipest mesh and aluminised screen (NH-AS).

\begin{tabular}{lccccc}
\hline Shelter & \multicolumn{5}{c}{ Nutritional parameters } \\
\cline { 2 - 6 } typologies & $\mathrm{N}^{\mathrm{z}}$ & $\mathrm{P}$ & $\mathrm{K}$ & $\mathrm{Na}$ & $\mathrm{Cl}$ \\
\hline MG & $42.1 \mathrm{a}^{\mathrm{y}}$ & $8.2 \mathrm{a}$ & $65.7 \mathrm{~b}$ & $6.1 \mathrm{a}$ & $51.3 \mathrm{a}$ \\
$\mathrm{BG}$ & $41.0 \mathrm{a}$ & $8.3 \mathrm{a}$ & $80.6 \mathrm{a}$ & $5.7 \mathrm{a}$ & $49.7 \mathrm{a}$ \\
$\mathrm{NH}$ & $21.9 \mathrm{c}$ & $4.6 \mathrm{c}$ & $50.0 \mathrm{c}$ & $5.9 \mathrm{a}$ & $52.6 \mathrm{a}$ \\
NH-AS & $32.5 \mathrm{~b}$ & $6.6 \mathrm{~b}$ & $49.1 \mathrm{c}$ & $5.8 \mathrm{a}$ & $51.4 \mathrm{a}$ \\
\hline
\end{tabular}

$\mathrm{z}_{1} \mathrm{mg} \cdot \mathrm{g}^{-1}=1000 \mathrm{ppm}$.

${ }^{\mathrm{y}}$ Means within a column with the same letter are not significantly different at $P<0.05$ (analysis of variance and least significant difference test). $n=6$.

different growth responses in baby rubber plants. At the end of the experimental period, baby rubber plants grown in a net house with antipest mesh and thermo-reflective aluminised screen showed the highest values in all growth parameters assessed. The high light transmitted in the net house with only antipest mesh may result in photoinhibition and consequently in an increase in $\mathrm{R}$ and $\mathrm{B}$ values in leaves. Under low-light conditions, there was an increase of chlorophylls andN and $\mathrm{P}$ leaf concentration in baby rubber plants. Neither the $\mathrm{K}$ concentration in leaves nor the $\mathrm{Na}$ or $\mathrm{Cl}$ concentrations showed any relationship with the light intensity: Leaf concentrations did not vary under different types of shelter and covering material. Overall, our results suggest the importance of comprehensive studies of the effects of different types of shelter and covering materials in the growth and physiological parameters of ornamental plants to help the growers and gardeners to select the most adequate type of shelter and covering material for the production of any given species. Finally, we recommend the growth of this species under net house with antipest mesh and aluminised screen to produce more saleable plants.

\section{Literature Cited}

Andersen, P.C., G.W. Knox, and J.G. Norcini. 1991. Light intensity influences growth and leaf physiology of Aucuba japonica 'Variegata'. HortScience 26:1485-1488.
Bres, W. and M. Jerzy. 2008. Changes of nutrient concentration in chrysanthemum leaves under influence of solar radiation. Agron. Res. 6:435444.

Callejón-Ferre, A.J., F. Manzano-Agugliaro, M. Díaz-Pérez, A. Carreño-Ortega, and J. PérezAlonso. 2009. Effect of shading with aluminised screens on fruit production and quality in tomato (Solanum lycopersicum L.) under greenhouse conditions. Span. J. Agr. Res. 7:41-49.

Chen, J., Q. Wang, D.B. McConnell, and R.J. Henny. 2005a. Responses of tropical foliage plants to interior low light conditions. Acta Hort. 669:51-56.

Chen, J., D.B. McConnell, R.J. Henny, and D.J. Norman. 2005b. The foliage plant industry. Hort. Rev. 31:47-112.

Cheon, I.H., W. Oh, J.H. Park, and K.S. Kim. 2006 Long day and high photosynthetic photon flux promote the growth and flowering of Cyclamen persicum. Hort. Environ. Biotechnol. 47:353358.

Close, D.C., C.L. Beadle, and M.J. Hovenden. 2001. Cold-induced photoinhibition and foliar pigment dynamics of Eucalyptus nitens seedlings during establishment. Austral. J. Plant Physiol. 28:1133-1141.

Csáky, A.G. and M.A. Martínez-Grau. 1998. Técnicas experimentales en síntesis orgánica. 2nd ed. Síntesis, Madrid, Spain.

Currey, C.J. and R.G. Lopez. 2015. Biomass accumulation and allocation, photosynthesis, and carbohydrate status of New Guinea impatiens, geranium, and petunia cuttings are affected by photosynthetic daily light integral during root development. J. Amer. Soc. Hort. Sci. 140:542-549.

de Groot, C.C., L.F.M. Marcelis, R. van den Boogaard, and H. Lambers. 2002. Interactive effects of nitrogen and irradiance on growth and partitioning of dry mass and nitrogen in young tomato plants. Funct. Plant Biol. 29:1319-1328.

Di Benedetto, A. 2004. Cultivo intensivo de especies ornamentales: Bases científicas y tecnológicas. Editorial Facultad Agronomia, Universidad de Buenos Aires, Argentina.

Dominguez, G.B., H. Mibus-Schoppe, and K. Sparke. 2017. Evaluation of existing research concerning sustainability in the value chain of ornamental plants. Eur. J. Sustain. Dev. 6:1119.

Evans, J. and H. Poorter. 2001. Photosynthetic acclimation of plants to growth irradiance: The relative importance of specific leaf area and nitrogen partitioning in maximizing carbon gain. Plant Cell Environ. 24:755-767.

Fernandez-Rodriguez, E.J., F. Camacho Ferre, M.T. Lao Arenas, V.P. Gómez, A. Kenig, and S. Jimenez. 2002. Effects of aluminized shading screens vs whitewash in a non-heated greenhouse temperature. Acta Hort. 614:427432.

Fisher, P.R. and E. Runkle. 2004. Managing lighting in the greenhouse: Why is it important? p. 9-17. In: P.R. Fisher and E. Runkle (eds.). Lighting up profits: Understanding greenhouse lighting. Meister Media Worldwide, Willoughby, $\mathrm{OH}$.

Frantz, J.M. and P. Ling. 2011. Growth, partitioning, and nutrient and carbohydrate concentration of Petunia hybrida Vilm. are influenced by altering light, $\mathrm{CO}_{2}$, and fertility. HortScience 46:228235.

García-Caparrós, P., A. Llanderal, M. Pestana, P.J. Correia, and M.T. Lao. 2016. Tolerance mechanisms of three potted ornamental plants grown under moderate salinity. Scientia Hort. 201:84 91.
García-Caparrós, P., A. Llanderal, A. El-Tarawy, J. Majsztrik, and M.T. Lao. 2017. Response of container-grown confeti tree irrigated with runoff water. HortTechnology 27:625-630.

Garland, K.F., S.E. Burnett, L.B. Stack, and D.L. Zhang. 2010. Minimum daily light integral for growing high-quality coleus. HortTechnology 20:929-933.

Gaurav, A.K., D.V.S. Raju, T. Janakiram, B. Singh, R. Jain, and S.G. Krishnan. 2015. Effect of shade levels on production and quality of cordyline (Cordyline terminalis). Intl. J. Agr. Sci. 85:931-935.

Hatamian, M. and H. Salehi. 2017. Physiological characteristics of two rose cultivars (Rosa hybrida L.) under different levels of shading in greenhouse conditions. J. Ornamental Plants 7:147-155.

Healy, W.E., R.D. Heins, and H.F. Wilkins. 1980. Influence of photoperiod and light quality on lateral branching and flowering of selected vegetatively-propagated plants. J. Amer. Soc. Hort. Sci. 105:812-816.

Henny, R.J. and J. Chen. 2003. Cultivar development of ornamental foliage plants. Plant Breed. Rev. 23:245-290.

Hogue, E., G.E. Wilcow, and D.J. Cantliffe. 1970. Effect of soil $\mathrm{P}$ on phosphate fraction in tomato leaves. J. Amer. Soc. Hort. Sci. 95:174-176.

Hong, J., J.S. Lee, and B.H. Kwack. 1994. Influence of light intensity and quality, and fertilizer on growth and leaf variegation of Codiaeum variegatum 'Yellow Jade' for indoor landscaping. J. Kor. Soc. Hort. Sci. 35:610-616.

Hughes, N.M., H.S. Neufeld, and K.O. Burkey. 2005. Functional role of anthocyanins in highlight winter leaves of the evergreen herb Galax urceolata. New Phytol. 168:575-587.

Hutchinson, V.A., C.J. Currey, and R.G. Lopez. 2012. Photosynthetic daily light integral during root development influences subsequent growth and development of several herbaceous annual bedding plants. HortScience 47:856860.

Ilyas, S., S. Nazi, F. Aslam, Z. Parveen, and A. Ali. 2014. Chemical composition of essential oil from in vitro grown Peperomia obtusifolia through GC-MS. Pak. J. Bot. 46:667-672.

Islam, M.S., M. Jalaluddin, J.O. Garner, M. Yoshimoto, and O. Yamakawa. 2005. Artificial shading and temperature influence on anthocyanin compositions in sweet potato leaves. HortScience 40:176-180.

Jeong, K.Y. and C.C. Pasian. 2007. Response of six Begonia species to different shading levels. Acta Hort. 761:215-220.

Jimenez, R. 1986. Estudio climático del Invernadero Solar Enterrado (INSOLE). Actas del II Congreso Nacional de la Sociedad de Ciencias Horticolas (SECH) 1:273-282.

Kaul, R.B. 1977. The role of the multiple epidermis in foliar succulence of Peperomia (Piperaceae). Bot. Gaz. 138:213-218.

Kim, J., S.W. Kang, C.H. Pak, and M.S. Kim. 2012. Changes in leaf variegation and coloration of english ivy and polka dot plant under various indoor light intensities. HortTechnology 22:4955.

Kittas, C., A. Katsoulas, and A. Baille. 2003. Influence of aluminized thermal screens on greenhouse microclimate and night transpiration. Acta Hort. 614:387-392.

Krom, M.D. 1980. Spectrophotometric determination of ammonia: Study of a modified Berthelot reaction using salicylate and dicholoroisocyanurate. Analyst (Lond.) 105:305-316.

Kubatsch, A., H. Gruneberg, and C. Ulrichs. 2007. The effect of low light intensity and 
temperature on growth of Schefflera arboricola in interior landscapes. HortScience 42:65-67.

Lachica, M., A. Aguilar, and J. Yanez. 1973. Análisis foliar: Métodos utilizados en la estación experimental del Zaidín. Anales de Edafologia y Agrobiologia 32:1033-1047.

Lambers, H., F.S. Chapin, and T.L. Pons. 1998. Photosynthesis, respiration, and long distance transport, p. 34. In: Plant physiological ecology. Springer-Verlag, New York.

Lao-Arenas, M.T., S. Jimenez, E.J. Fernandez, and F. Camacho. 2003. Climatic parameters of solar buried greenhouse (Insole) under Mediterranean conditions. Acta Hort. 614:453-460.

Li, Q., J. Chen, D.B. McConnell, and R.J. Henny. 2007. A simple and effective method for quantifying leaf variegation. HortTechnology 17:285-288.

Lütken, H., J.L. Clarke, and R. Müller. 2012. Genetic engineering and sustainable production of ornamentals: Current status and future directions. Plant Cell Rep. 31:1141-1157.

Maathuis, F.J. 2013. Sodium in plants: Perception, signalling, and regulation of sodium fluxes. J. Expt. Bot. 65:849-858.

Marschner, H. 1995. The mineral nutrition of higher plants. 2nd ed. Academic Press, London.

Meng, P., Y. Ge, Q. Cao, J. Chang, P. Pan, C. Liu, Y. Lu, and S.X. Chang. 2008. Growth and photosynthetic responses of three Lycoris species to levels of irradiance. HortScience 43:134-137.

Mengel, K. and E.A. Kirkby. 2001. Principles of plant nutrition. Kluwer Academic Publishers, Dordrecht, The Netherlands.

Merzlyak, M.N., O.B. Chivkunova, A.E. Solovchenko, and K.R. Naqvi. 2008. Light absorption by anthocyanins in juvenile, stressed, and senescing leaves. J. Expt. Bot. 59:3903-3911.

Miralles, J., J.J. Martínez-Sánchez, J.A. Franco, and S. Bañón. 2011. Rhamnus alaternus growth under four simulated shade environments: Morphological, anatomical and physiological responses. Scientia Hort. 127:562-570.

Nam, Y.K., H.R. Kwack, and B.H. Kwack. 1997. Different extents of leaf-variegation in Epipremnum aureum as influenced by different light levels. J. Kor. Soc. Hort. Sci. 38:537-540.

Nemali, K.S. and M.W. van Iersel. 2004. Acclimation of wax begonia to light intensity: Changes in photosynthesis, respiration, and chlorophyll concentration. J. Amer. Soc. Hort. Sci. 129:745751.

Oh, W., I.H. Cheon, K.S. Kim, and E. Runkle. 2009. Photosynthetic daily light integral influences flowering time and crop characteristics of Cyclamen persicum. HortScience 44:341-344.

Pennisi, S., M.W. van Iersel, and S.E. Burnett. 2005. Photosynthetic irradiance and nutrition effects on growth of English ivy in subirrigation systems. HortScience 40:1740-1745.

Pérez-Saiz, M., F.J. Barbero-Francisco, and M.T. Lao. 2017. Spectral distribution of light under different structures and cover materials employed in Mediterranean greenhouses. Acta Hort. 1170:905-914.

Pramuk, L.A. and E.S. Runkle. 2005. Modeling growth and development of Celosia and Impatiens in response to temperature and photosynthetic daily light integral. J. Amer. Soc. Hort. Sci. 130:813-818.

Rouphael, Y., M. Cardarelli, E. Rea, and G. Colla 2008. The influence of irrigation system and nutrient solution concentration on potted geranium production under various conditions of radiation and temperature. Scientia Hort. 118:328-337.

Sarracino, J.M., R. Merrit, and C.K. Chin. 1992. Morphological and physiological characteristics of Leea coccinia and Leea rubra in response to light flux. HortScience 27:400-403.

Scuderi, D., F. Giuffrida, S. Toscano, and D. Romano. 2012. Growth, physiological response, and quality characteristics of weeping fig in response to shading levels and climatic conditions. HortScience 47:1586-1592.

Shen, G.W. and J.G. Seeley. 1983. The effect of shading and nutrient supply on variegation and nutrient content of variegated cultivars of Peperomia obtusifolia. J. Amer. Soc. Hort. Sci. 108:429-433.

Singh, M.C., A. Yousuf, and J.P. Singh. 2016. Greenhouse microclimate modeling under cropped conditions-A review. Res. Environ. Life Sci. 9:1552-1557.

Sipes, D.L. and I.P. Ting. 1985. Crassulacean acid metabolism and crassulacean acid metabolism modifications in Peperomia camptotricha. Plant Physiol. 77:59-63.

Stamps, R.H. 1995. Effects of shade level and fertilizer rate on yield and vase life of Aspidis- tra elatior 'Variegata' leaves. J. Environ. Hort. 13:137-139.

Stamps, R.H. 2009. Use of colored shade netting in horticulture. HortScience 44:239-241.

Stanton, K.M., S.S. Weeks, M.N. Dana, and M.V. Mickelbart. 2010. Light exposure and shade effects on growth, flowering, and leaf morphology of Spirea alba Du Roi and Spirea tomentosa L. HortScience 45:19121916.

Taiz, L. and E. Zeiger. 2012. Plant physiology. 5th ed. Sinauer Associates, Sunderland, MA.

Torres, A.P. and R.G. Lopez. 2011. Photosynthetic daily light integral during propagation of Tecoma stans influences seedling rooting and growth. HortScience 46:282-286.

Villegas, E., M. Pérez, and M.T. Lao. 2006. Influence of lighting levels by shading cloths on Cyclamen persicum quality. Acta Hort. 711:145-150.

Vladimirova, S.V., D.B. McConnell, M.E. Kane, and R.W. Henley. 1997. Morphological plasticity of Dracaena sanderana 'Ribbon' in response to four light intensities. HortScience 32:1049-1052.

Wellburn, A. 1994. The spectral determination of chlorophylls a and b, as well as total carotenoids, using various solvent with spectrophotometers of different resolution. J. Plant Physiol. 144:307-313.

White, P.J. and M.R. Broadley. 2001. Chloride in soils and its uptake and movement within the plant: A review. Ann. Bot. 88:967988.

Zhang, B.B., W.B. Jiang, M.L. Weng, and J. Han. 2009. Research progress on photosynthetic characteristics of horticulture and landscape tree species under shading condition. Nonwood Forest Res. 27:115-119.

Zhang, H., H. Zhong, J. Wang, X. Sui, and N. Xu. 2016. Adaptive changes in chlorophyll content and photosynthetic features to low light in Physocarpus amurensis "Maxim" and Physocarpus opulifolius "Diabolo". PeerJ 4: e2 125 .

Zhao, D., Z. Hao, and J. Tao. 2012. Effects of shade on plant growth and flower quality in the herbaceous peony (Paeonia lactiflora Pall.). Plant Physiol. Biochem. 61:187-196. 